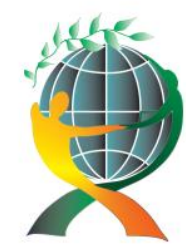

\author{
(online) $=$ ISSN $2285-3642$ \\ ISSN-L = 2285 - 3642 \\ Journal of Economic Development, Environment and People \\ Volume 5, Issue 2, 2016
}

URL: http://jedep.spiruharet.ro

e-mail: office jedep@spiruharet.ro

\title{
Organic Production Model of Business and the Concept of Corporate Social Responsibility
}

\author{
Ekaterina Arabska ${ }^{1}$, Venelin Terziev ${ }^{2}$ \\ ${ }^{1}$ University of Agribusiness and Rural Development - Plovdiv, Bulgaria \\ ${ }^{2}$ Vasil Levski National Military University - Veliko Tarnovo, Bulgaria
}

\begin{abstract}
The concept of corporate social responsibility (CSR) considering competitiveness and sustainability issues in contemporary globalizing world is closely linked to organic production being a production system applying holistic approaches in the overall management and production activities and assurance of the highest degree of conformability to sustainable use and preservation of resources. The paper examines the organic production as a business model corresponding to the spheres of CSR regarding society, environment, human capital and work conditions, knowledge and education. The focus in on sustainable business practices in organic production assessed in the study from the point of view of management, environment, human resources, public relations and business environment considered in five dimensions: economic, social, environmental, cultural and accountability.
\end{abstract}

Keywords: sustainable development; accountability; sustainable management practices.

Jel Codes: Q01, M 14

\section{Introduction}

Contemporary global threats in relation to climate change, limitations in natural resources, challenges in quality and distribution of human resources, crises in financial an economic sphere etc. require integrated approaches towards managerial, social and ecological factors in the creation of a long-term value in organizations and markets based on the ethical norms and responsible behavior. The corporate social responsibility is accepted as the responsibility and accountability of the organizations for the impacts of their decisions and activities on society and environment implemented in conditions of transparency and ethical behavior and contributing to sustainable development, human health and society welfare. Being integrated in the organizations at all the levels and expressed by their inner and outer interactions and

\footnotetext{
${ }^{1}$ Email address: katya_arabska@abv.bg

${ }^{2}$ Email address: terziev@skmat.com
} 


\author{
(online) $=$ ISSN $2285-3642$ \\ ISSN-L = $2285-3642$ \\ Journal of Economic Development, Environment and People \\ Volume 5, Issue 2, 2016
}

URL: http://jedep.spiruharet.ro

e-mail: office jedep@spiruharet.ro

relations, it considers the expectations of all the parties and is in correspondence to the legislation concerning social and ecological issues and relevant international norms in the implementation of socially responsible initiatives (Nikolova\&Yordanova, 2014).

The question of Corporate Social Responsibility (CSR) is of a particular importance because it gives a terminological clearness and introduces the basic positions and limitations from the point of view of the organizations and their roles in the balancing of the three pillars of sustainable development - economic growth, social development and environmental protection (Zahariev, 2013, 232). Corporate social responsibility, also called corporate conscience, citizenship, social performance, sustainable responsible business, is a form of corporate self-regulation integrated in a business model. CSR policy functions as a built-in mechanism of self-regulation by which the business controls and provides its active compliance to the law, ethical standards and international norms (Pop, Dina, \& Martin, 2011).

In the last few decades CSR has been developing a narrow and often marginalized notion into a complex and multilateral concept (Cochran, 2007). Corporate social responsibility (CSR) and corporate social irresponsibility (CSI) are determined as key tasks which could lead to development of a number of international policies encouraging CSR and discouraging CSI (Windsor, 2013). CSR is a policy that organizations voluntarily accept and implement in their business strategies in a way showing their longterm engagement in sustainable development of their business, society and environment (Pop, Dina, \& Martin, 2011). CSR is accepted as an activity which is not of a single performance but a sustainable process. The concept is developing into a successful business strategy for sustainable development supporting organizations in the raise of their influence on the market and also in establishing a positive public image (Nikolova et al., 2014; Bakardjieva, 2009).

Social responsibility is an element of the corporate culture, considering the flexibility and security (flexicurity) and management of multiformity in a number of spheres and business practices (Fig. 1).

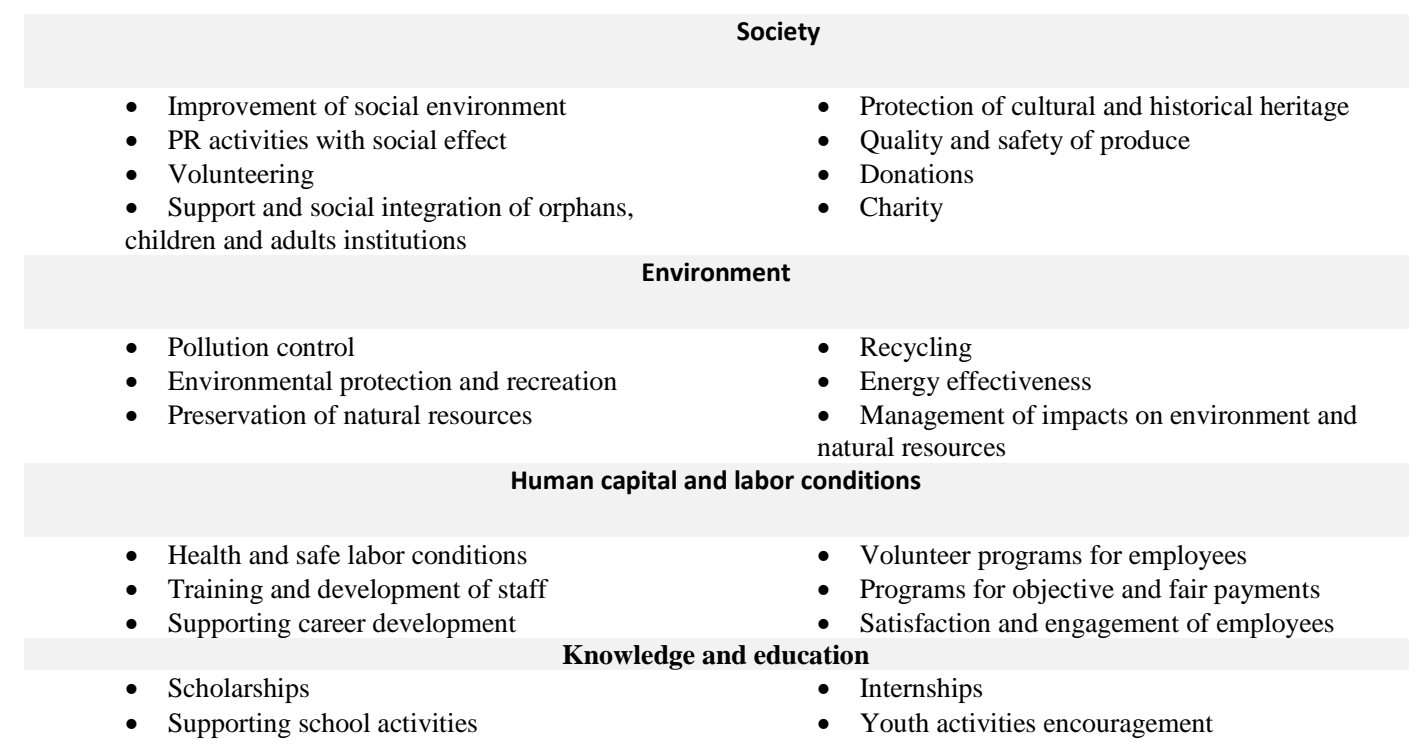

Fig. 1. Main spheres of CSR (According to the Bulgarian network for CSR with small modifications) 


\author{
(online) $=$ ISSN $2285-3642$ \\ ISSN-L = 2285 - 3642 \\ Journal of Economic Development, Environment and People \\ Volume 5, Issue 2, 2016 \\ URL: http://jedep.spiruharet.ro \\ e-mail: office jedep@spiruharet.ro
}

In the EU Green book the CSR is the main instrument for creation of new places of work and sustainable economic development and encouragement of a more effective regarding use of resources, greener and more competitive economy is one of the main priorities of Europe 2020 (Pop, Dina, \& Martin, 2011). Discussing the concept from the point of view of the EC's definition from 2001 as a voluntary integration of social and ecological concerns in the activities and interactions of the organizations, the CSR could be scrutinized as based on three fundamental concepts: voluntary nature of initiatives, consciousness and attention on the relations to markets and hence consumers, and inclusion of all stakeholders (Viola, Ruggeri, \& Rotondo, 2013). This means that social responsible business is that paying more attention to environment, employment and consumers. Discussing agricultural and food sector as a green-oriented one which could be social responsible through the implementation of the right policies regarding environmental protection, creation of new "green" employees and supply of goods and services (Viola, Ruggeri, \& Rotondo, 2013). Talking about the significance of natural environmental orientation, it is viewed as comprising of three components: entrepreneurship, corporate social responsibility and environment commitment (Menguc\&Ozanne, 2005).

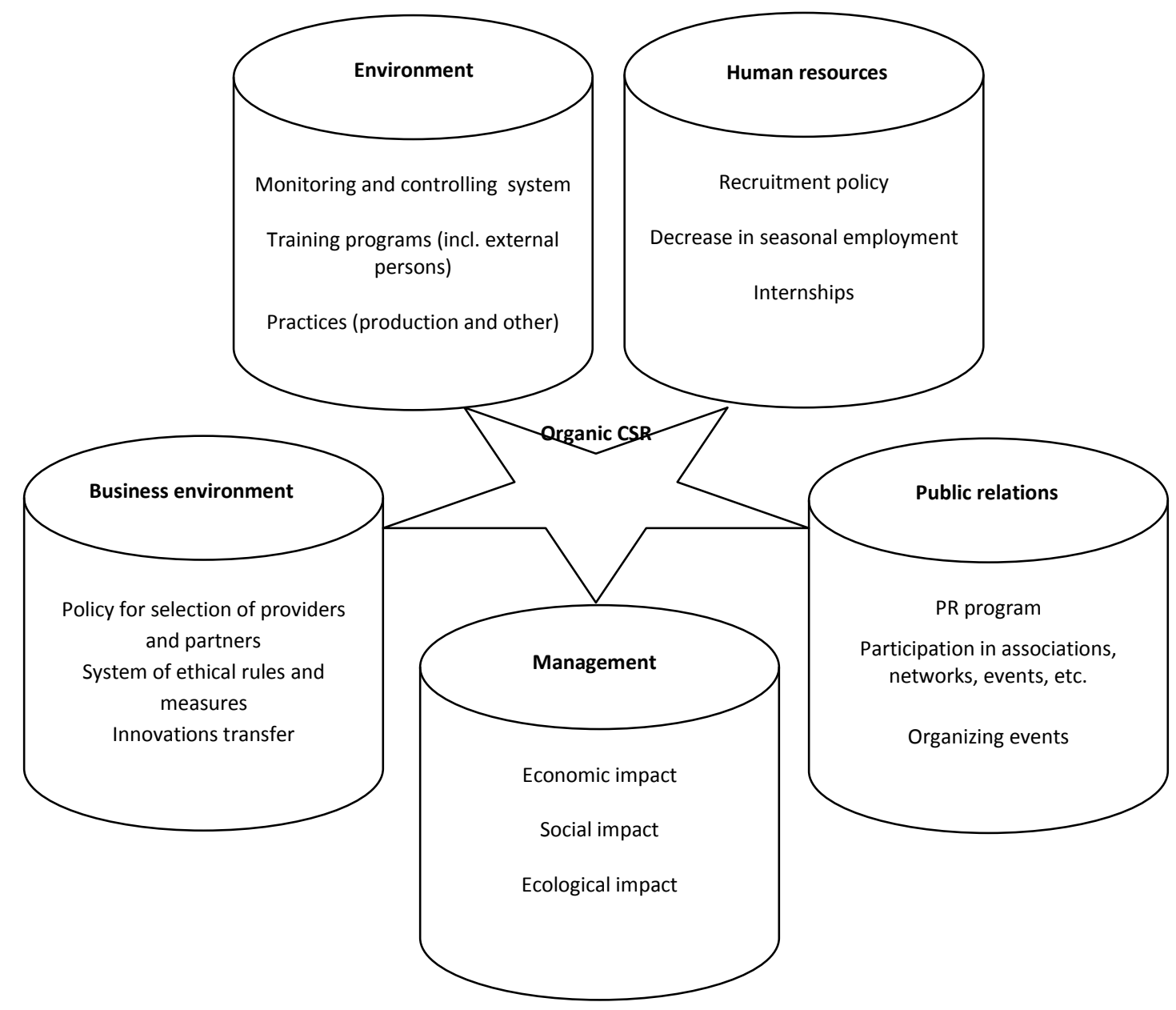

Fig. 2. Extrapolation of the CSR to organic production business model (According to Arabska $(2014,64)$ 


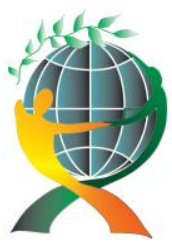

\author{
(online) $=$ ISSN $2285-3642$ \\ ISSN-L = $2285-3642$ \\ Journal of Economic Development, Environment and People \\ Volume 5, Issue 2, 2016 \\ URL: $\underline{\text { http://jedep.spiruharet.ro }}$ \\ e-mail: office jedep@spiruharet.ro
}

The examination of the CSR in present article is connected to the main idea of organic production "Good for nature, good for you" as stated on the web-site of the European Commission. Agriculture and rural development. Organic farming: http://ec.europa.eu/agriculture/organic/) and concerns the stakeholders in the sector: state, business (producers, processors, distributors, traders), scientific and educational organizations, on the one hand, and consumers, non-governmental organizations, media, on the other, considering that the relations between all this are very complex.

Organic production as a way of achieving sustainable growth is determined in the three main aspects of sustainable development: economic sustainability - increasing competitiveness, strong market orientation and increased incomes; social sustainability - bigger responsibility towards consumers' demands, improving food quality and safety; regional development; ecologic sustainability - unified framework, effective implementation and control, standards of protection of environment and health (Arabska, 2014).

Furthermore, organic production is considered in two aspects of protection: environmental protection by using management practices that do not have adverse effects on environment, and the health of consumers - by the provision of organic products (Argyropoulos et al., 2013). Recently, cultural dimension and accountability dimension of sustainability are also added in the Best Practice Guideline for Agriculture and Value Chains (2013). Organic production is considered as a business model applying sustainable managerial and business practices which implies the CSR at the greatest extent (Fig. 2).

The study presented in the paper examines sustainable business practices in organic production, making assessments of five spheres of interdependencies of organic production and corporate social responsibility: management, environment, human resources, public relations and business environment, all considered in the five sustainability dimensions: economic, social, environmental, cultural and accountability.

\title{
2. Methodology
}

Five categories of assessment criteria are chosen as described in the introduction (Fig. 2): management, environment, human resources, public relations and business environment, each comprising three sub-criteria which are assessed on the scale from 1 to 5 (1 - very low, 2 - low, 3 - satisfactory, 4 good, 5 - very good), according to the conformity of organic production business model to the corporate social responsibility issues interlinked with sustainable development. Then the values of each criterion is calculated as an average of sub-criteria's assessments. That way the maximum value of each criterion could be 15 , the minimum -1 . The assessments were made in a round-table discussion by three experts who gave their opinions according to the presented criteria and scale and according to their knowledge and experience in the Republic of Bulgaria.

\section{Results}

Assessments of the sub-criteria of "Management" show the highest values for the ecological impact of organic agriculture and the lowest for the social impact (Fig. 3). Economic impact is assessed as high as well. 


\author{
(online) $=$ ISSN $2285-3642$ \\ ISSN-L = 2285 - 3642 \\ Journal of Economic Development, Environment and People \\ Volume 5, Issue 2, 2016 \\ URL: http://jedep.spiruharet.ro \\ e-mail: office jedep@spiruharet.ro
}

The results show that the experts are not convinced in the social impact of the sector and underline the environmental dimension as the most commented one as a contribution in a number of documents and studies concerning organic production.

In the sphere of environment the assessments are with the highest values for organic production practices and training programs in the field of environmental protection and healthy human living, including those organized in organic farms for visitors of all ages (Fig. 4). The trust in the monitoring and control system in organic production is expressed as well.

Discussed sub-criteria for "Human resources" show good results, almost identical for recruitment policy, decrease in seasonal employment and internships (Fig. 5).

Among the public relations PR program is the best one assessed followed by the organization of events in the organic farms (Fig. 6). The satisfactory assessment of the participation in associations, networks, events, etc. is substantiated by the situation in the sector in Bulgaria and the low activity in the field of networking which influences the experts' assessments. In the sphere of business environment the situation is almost the same presenting as a whole not much than good results in innovation transfer, system of ethical rules and measures and policy for selection of providers and partners (Fig. 7).

Turning back to the five examined spheres and calculating the average assessments values (Fig. 8) environment is determined as the most important one in the link of organic production to CSR, followed by management, human resources, public relations and business environment.

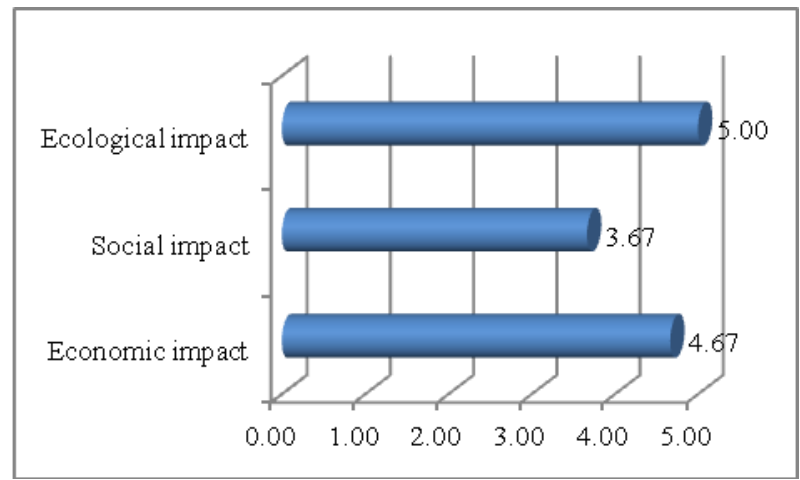

Fig. 3. Experts' average assessment of the sphere of "Management"

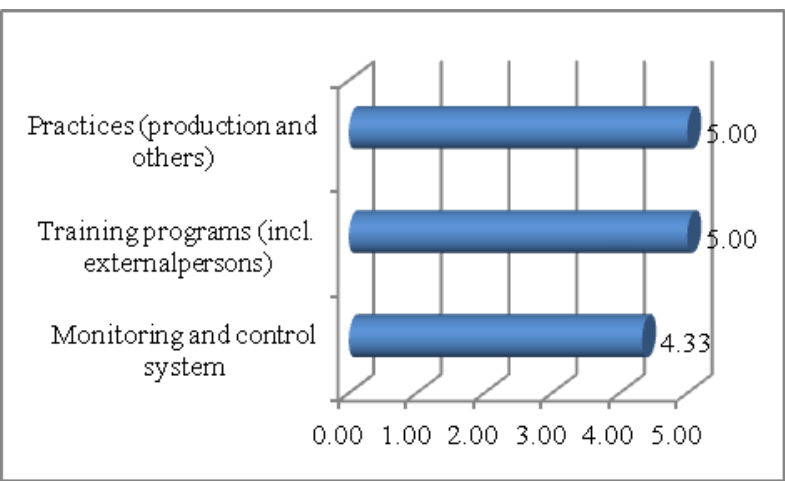

Fig. 4. Experts' average assessment of the sphere of "Environment" 


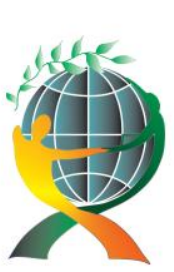

\author{
(online) $=$ ISSN $2285-3642$ \\ ISSN-L = 2285 - 3642 \\ Journal of Economic Development, Environment and People \\ Volume 5, Issue 2, 2016
}

URL: http://jedep.spiruharet.ro

e-mail: office jedep@spiruharet.ro

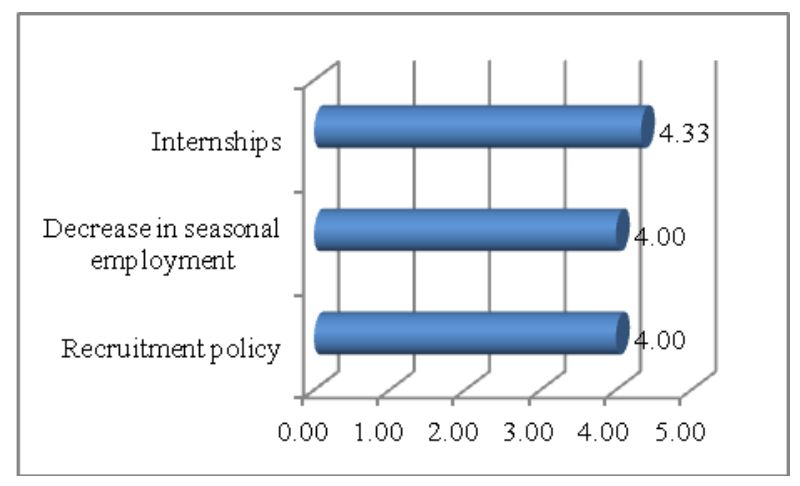

Fig. 5. Experts' average assessment of the sphere of "Human resources"

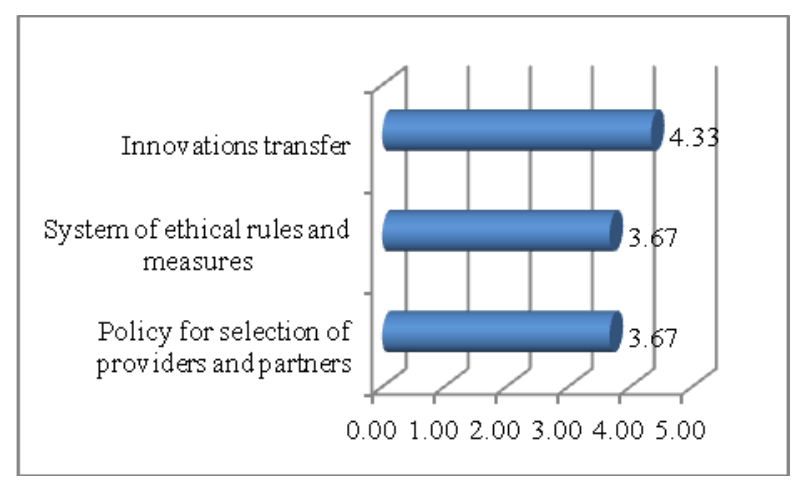

Fig. 7. Experts' average assessment of the sphere of "Business environment"

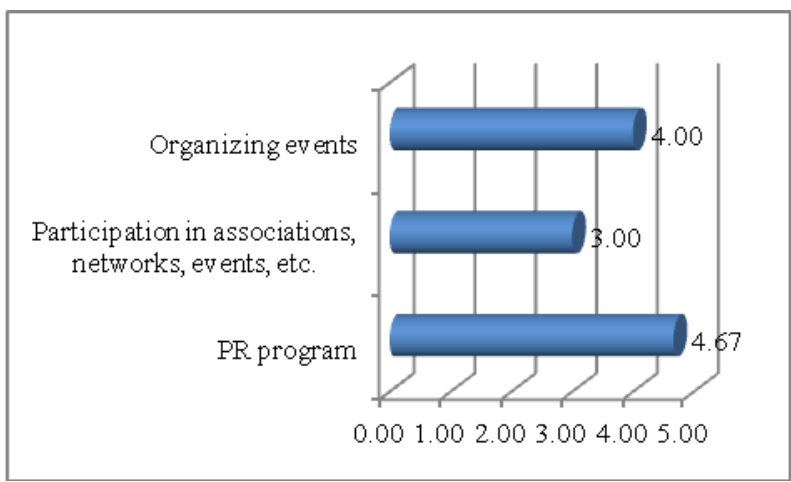

Fig. 6. Experts' average assessment of the sphere of "Public relations"

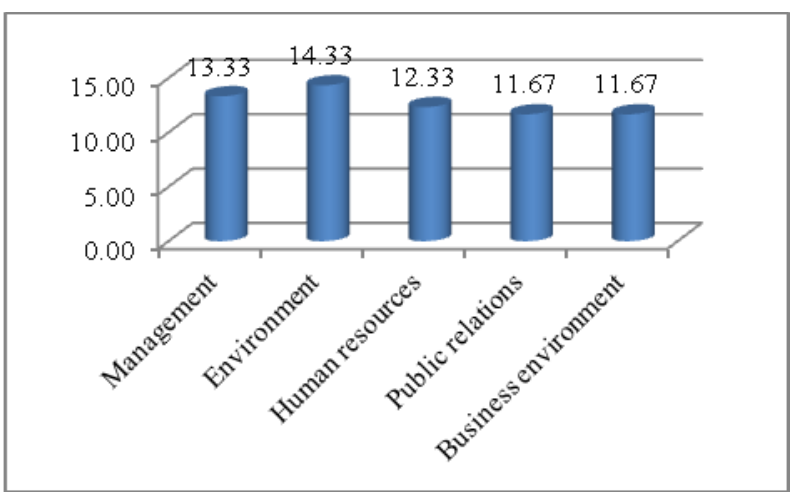

Fig. 8. Experts' average assessment of all the five examined spheres

\title{
4. Discussion
}

The main results of current investigation, although based on the specific situation of organic sector development in the Republic of Bulgaria, show that the business model of organic production fits very well to the key point of the concept of CSR being a sector implementing integrated and holistic management activities of all the processes in the whole production cycle, i.e. having "a built-in and self-regulated mechanism" working according to the requirements of the strong legislative base and standards which is expressed by the certification procedures assuring consumers' and society trust in organic.

Organic production as a sector having a great potential for making significant contributions to sustainable development (and thus put as a priority in a number of strategic and program documents on different levels, especially by the European Union and international community) leads to various positive influences on environment, society and economy. In other words, the concerns of planet, people and profit are the basic one in the essence of the production methods and the practices in management and the sector development is marked by a progress in last years and a great public attention namely because of 


\author{
(online) $=$ ISSN $2285-3642$ \\ ISSN-L = $2285-3642$ \\ Journal of Economic Development, Environment and People \\ Volume 5, Issue 2, 2016 \\ URL: $\underline{\text { http://jedep.spiruharet.ro }}$ \\ e-mail: office jedep@spiruharet.ro
}

high ethics and strong rules reasons, in balanced approaches for sustainable development, underpinned by corporate social responsibility.

\title{
5. Conclusion
}

As a result of the main discussions, a definition of organic production business model is given as follows: organic production business model is a holistic production and managerial method in sustainable agriculture ensuring overall management and answering a number of requirements regarding environmental protection, food quality and safety and human health which responsibly uses, protects and restores natural resources, supports the preservation of the components of environment (soil, water, biodiversity, landscape), stabilizes ecosystems and creates opportunities for positive economic and social growth. Organic production is a way of investments in production processes creating employment in environmentally friendly activities, providing information and increased social consciousness in connection to the principles of sustainable development.

Organic production is a green oriented sector applying sustainable business practices and implying an overall management of processes and integrated approaches - the monitoring and control are not focused on the final products but on the system functioning. It is a business model implying the principles of corporate social responsibility in five main directions: management, environment, human resources, public relations and business environment, which are influenced by the specific development of countries and regions underlining the importance of relevant state policies encouraging CSR applied in different sectors and initiatives, as well as the broad community participation.

\section{Acknowledgements}

The authors would like to thank to the experts participating in the round table organized: Doreta Dzhineva, Kirilka Nenkova, Evgenia Velichkova, for making the assessments.

\section{References}

[1] Arabska, E. (2014). Organic production: innovations and sustainability challenges in development framework and management. Lambert Academic Publishing. ISBN 978-3-659-56379-9.

[2] Argyropoulos, C., Tsiafouli, M. A., Sgardelis, S. P., \& Pantis, J. D. (2013), Organic farming without organic products. Land Use Policy 32, 324-328

[3] Bakardjieva, R. (2009). Corporate social responsibility of the firms in Bulgaria. Economic studies No2, 33-63.

[4] Best Practice Guideline for Agriculture and Value Chains. (2013). Developed by Sustainable Organic Agriculture Action Network and approved for the global organic movement by IFOAM.

http://www.ifoam.org/sites/default/files/best practice guideline v1.0 ratified.pdf 


\author{
(online) $=$ ISSN $2285-3642$ \\ ISSN-L = $2285-3642$ \\ Journal of Economic Development, Environment and People \\ Volume 5, Issue 2, 2016 \\ URL: http://jedep.spiruharet.ro \\ e-mail: office jedep@spiruharet.ro
}

[5] Cochran, P. L. (2007), The evolution of corporate social responsibility. Business Horizons 50, 449-454.

[6] CSR spheres. Bulgarian network for CSR: http://csr.bg/social-responsibility/range. Accessed 12/2014.

[7] European commission. Agriculture and rural development. Organic farming:

http://ec.europa.eu/agriculture/organic/. Accessed 12/2014.

[8] Menguc, B., \& Ozanne, L. K. (2005) Challenges of the "green imperative": a natural resource-based approach to the environmental orientation-business performance relationships. Journal of Business Research 58, 430438.

[9] Nikolova, N, Todorova, I., Nenova, N. (2014). Corporate social responsibility as a strategic priority in the competitive behaviour of the company. Scientific works "MathTech 2014", Bishop Konstantin Preslavski University of Shumen, Vol. 1, 333-340.

[10] Nikolova, N., Yordanova, I. (2014). Corporate social responsibility as a mechanism for the integration of economic, social and ecological goals of the organization. Proceedings of the Closing conference under the project "System of qualification and career development of the university teachers", Vasil Levski National Military University Veliko Tarnovo, Bulgaria, 219-229.

[11] Pop, O., Dina, G. C., \& Martin, C. (2011). Promoting the corporate social responsibility for a green economy and innovative jobs. Procedia Social and Behavioral Sciences 15, 1020-1023.

[12] Viola, I. , Ruggeri, F., \& Rotondo, G. (2013). Corporate social responsibility and green economy in the agri-food business. Quality - Access to Success, Volume 14, Issue suppl. 1, 151-156.

[13] Windsor, D. (2013), Corporate social responsibility and irresponsibility: A positive theory approach. Journal of Business Research Volume 66, Issue 10, October 2013, 1937-1944.

[14] Zahariev, E. (2013). Challenges before the industrial management: priorities and solutions. UARD Publishing house. ISBN 978-619-7048-14-8. 